\title{
Citizenship Education as Value Education and the Nation's Strengthening of Character for Citizens
}

\author{
Siti Anisah \\ Graduate School \\ Universitas Negeri Yogyakarta \\ Yogyakarta, Indonesia \\ siti.anisah2016@student.uny.ac.id
}

\author{
Marzsuki \\ Graduate School \\ Universitas Negeri Yogyakarta \\ Yogyakarta, Indonesia \\ marzuki@uny.ac.id
}

\begin{abstract}
Globalization gives a negative impact penetrates on shifting the culture of the nation. To overcome it every citizen should have the characteristics of a strong in the face of the current global. Education is how powerful that is believed to be preparing a generation of the nation in order to have a wide range of competence and character nationality. Citizenship education is a subject in the school has a purpose to prepare the citizens of countries that are good in understanding and cultivate the values of Pancasila in accordance with the philosophy of the nation and the Constitution of the Republic Indonesia. The methods used in the preparation of this paper was the library research. The results of the study, namely: civic education has a strategic position as a values education and strengthening of national character for citizens. The strengthening of character education in Indonesia was made the axis of education sourced from religion, Pancasila, the national cultural and educational purposes. Adopting the philosophy of $\mathrm{Ki}$ Hajar Dewantara character education include liver sporting (ethics), sports (kinesthetic), though think (literacy), and the aesthetics. Ministry of education develop a character value 18 crystallized into 5 main value consists of a religious, nationalistic, independent, mutual and integrity. Implementation of strengthening character education class with integrated in-based subjects.
\end{abstract}

Keywords-Citizenship education; Value education; The values of Pancasila; The strengthening of character.

\section{INTRODUCTION}

The globalization of modern and postmodern determine the footing in prestige race between countries superpower that leads to the discovery of the latest technologies within launch the first man-made satellite, "Sputnik 1 on October 4, 1957 by the Soviet Union and then followed by the United States of America with the launch a satellite "Explorer 1 on 31 June 1958. In June 1961, Forcen American air using the various facilities of the United States Space Satellite Network to Surveillance cataloged several 115 orbiting the Earth [1].

Globalization going through a system of information and communication network, a variety of inventions in the field of technology has removed the barriers of space and time, no territorial boundaries, countries, peoples, through space satellite [2]. The process of globalization has been torn and eroded forms of cultural identity of a people [3]. The phenomenon of globalization in addition to giving a positive impact, as well as negative impact; namely, pose a threat to the integrity of the nation because globalization is dominance and intervention in a new form. Cultural hegemony happens due to the influx of foreign culture download slide culture, values, and religion, are replaced with values that do not match with confidence and trust as well as prevailing norms, giving rise to various irregularities and trigger a change in attitude which resulted in forms of delinquency of teenagers are increasing and pose a threat to the culture [4]. Moral issues suggest that occurs among teenagers in Indonesia with the emergence of various cases of irregularities to affect the formation of adolescent characters in Indonesia [5]

Strong personality characteristics are needed and functionally able to live in the time of globalization because of the condition of the pluralistic society of Indonesia, is very high by a potential conflict of social. The characteristics that need to be owned by a citizen, namely: (a) the ability to view and analyze the problem as a member of the community of global; (b) the ability to cooperate with others in cooperative and responsibility; (c) the ability to understand, accept and tolerate, appreciate cultural differences; (d) the capacity to think critically and systemically; (e) a willingness to resolve conflicts and avoid violent manner; (f) a willingness to change her life; (g) the ability to finely tuned and defend human rights; and (h) a willingness to participate in politics at the local level, nationally and internationally [6].

Strengthen the sense of nationhood is a form of support for the realization of citizens who have the characteristics of a global solution is key and its implementation started with the strengthening of the understanding on the next generation of the nation through education. Filters that match the nation's cultural values i.e. religion, culture, national education goals and of Pancasila. Religion and culture are basic values. Humans as social beings, who lived a religious life and run in the community in accordance with the cultural habits of the society as a hereditary. Pancasila has been a basic State and way of life the nation of 
Indonesia since Indonesia became independent till now. The national education goals into value to manifest the life of the nation to a better future.

The Pancasila as the State can be said to be ideology "interstices" which addresses the contagiousness of individual and group understanding. Historically, the fifth Sila of Pancasila is a blend (synthesis) of the diversity of beliefs, understand and expectations are evolving. The first Sila is the formulation from all streams of religion and belief. The second Sila is a formulation of all understand and humanitarian social ideals which are nationwide. The third Sila is a formulation of Bhinneka ethnicity into the unity of the nation. The fourth Sila is the formulation of all understand about sovereignty. The fifth Sila is the formulation of all the familiar economic social justice [7]

Pancasila as the nation's view of life was supposed to be applied consistently in the life of society, nation, and State, so it has become an obligation for all citizens of Indonesia to implement it in your life every day. In this application of Pancasila, civilizing Pancasila required a course in the middle of Indonesia society. Means for civilizing Pancasila effective one through the process of values education and strengthening of character education. Values education in practice can be integrated into a variety of subjects [8]. As well as strengthening character education which is expected to address the decline of national character to humanize the human with the one of implementation through the strengthening character education-based classes with integrated into the subjects.

Citizenship education the charge is one of the primary and secondary education curricula as mandated in article 2, article 3, and article 37 of the act number 20 Year 2003 about national education system explained that the eyes citizenship education lessons expected to be instructive in developing rides for learners to be human that has fostered a love of land and water that is imbued by Pancasila values, the State Constitution of the Republic Indonesia Year 1945, the spirit of Bhinneka Tunggal Ika and the commitment of the State Union of Republic Indonesia. To accommodate new development and realization of education as the process of intelligence the life of the nation in the sense of intact and broadly, then the substance and the term or the name of the previous subject's civic education packaged in 2013 curriculum became the subjects of civics and citizenship.

The subjects of civics and citizenship focusing on the formation of the self in terms of diverse religions, socio-cultural, language, age, and ethnic groups to make the citizens of Indonesia are smart, skilled, and character that was mandated by The Pancasila and The Constitution of 1945. The discussion becomes more interesting as the citizenship education about values education and character strengthening for citizen will include the context of values education, civic education, strengthening the context of character education, then values education and strengthening characters in citizenship education.

\section{LITERATURE REVIEW}

\section{A. The Context of Values Education}

Viewed from the side, the value of education is one which is believed to be something valuable, worthy, and ideal for championed and developed in every action to educate. The value starts from the world of economics with the meaning of the price paid for a use of any of your goods or services, over time the value of belonging to the scope of the trigger on a moral ethic, kindness, and a final destination action, then enter a value in the discussion of philosophy, human qualities and objects [9]. Value with regard to responsibility, with regard to conscience, oblige and formal in nature that has characterized, such as (a) the value related to the subject; (b) the value of performing a practical context; and (c) the values regarding properties that are added by the object properties that are owned by objects [10].

Values education has objectives and approaches in the cultivation of the values. First, the approach begins with the receipt of certain social values by learners. Second, his approach to change learners' values incompatible with social values as desired. The methods used in this approach among other examples, positive and negative reinforcement, simulations, roleplaying and more [11]. Values education is intended to help you understand, realize, experienced and able to put in the integral values of life [12].

The experts have developed a variety of approaches to values education. In the context of Indonesia, Pancasila value source is in civilizing for the next generation of the nation cannot be released from the efforts of noble values education. Pancasila contains five fundamental values idealized into two conceptions. The first is as the basis of a State or Philosophische Grondslag which is defined as on the mind, philosophy, profuse, soul, a passion that profuse to form an independent Indonesia. The second is the view of life and a state ideology of the nation of Indonesia (Weltanschauung) [7].

Already a consensus together if the existence of Pancasila values must be understood with the hope it can be imbued by learners in daily life. Expressed by Notonagoro that the core essence of the essence of Pancasila are: (a) the Godhead as the essence of the first sila is the suitability of the substance with God; (b) the essence of humanity as the Sila second is conformity with human nature; (c) the Union as its essence the third Sila is compatibility with nature one; (d) the Populist as its essence the fourth Sila is the suitability of the substance with the people; (e) a justice as its essence is the fifth Sila of conformity with nature [13]. 
The Pancasila as the foundation of an ideal nation of Indonesia, which form the crystallization of the lofty values of Nations Indonesia, Pancasila has a message of moral and ethical values, the nation [12]. Therefore, the ideal foundation of life and this country can be a strong grounding in organizing values education in school, family, and community. All the values contained in the Pancasila is not just mere rhetoric as a symbol, but it is a philosophy or ideology of the nation must be fully realized in the life of nation and State.

The Pancasila as the national identity of Indonesia unique when compared with some other identity. Pancasila is not just physical but also became the symbol of the coat of arms in the form of psychic, because it reflects the character and behavior of human beings as citizens in Indonesia [14]. National identity is cultural values that already grow and develop from ancient tribal life in various aspects which are then compiled in a single unity of Indonesia became the national culture with reference to Pancasila and Bhineka Tunggal Ika spirit as the basis and direction of its development.

\section{B. The strengthening of national character}

The characters are also a device a good behavior for citizens [15]. The character is good for someone like honesty, responsibility, respect for others and other good values that can be realized in concrete actions in everyday life [16]. The pillars of character are universal consists of peace, cooperation, respect, happiness, honesty, humility, affection, responsibility, simplicity, tolerance and unity [17]. The character is a good attitude or behavior that includes honesty, courage, justice, and compassion that is owned by humans.

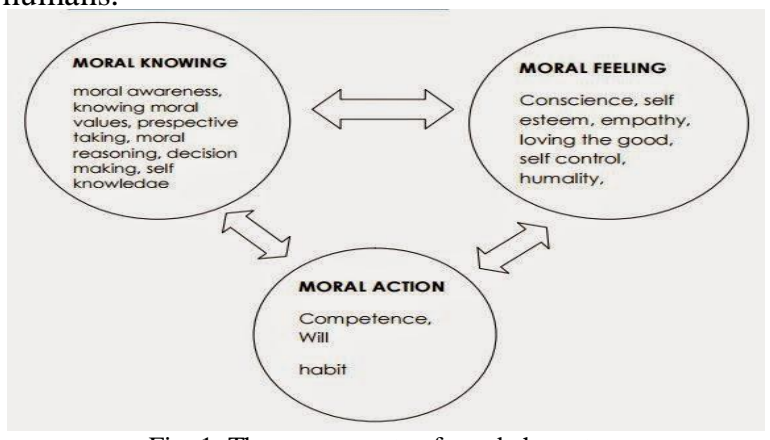

Fig. 1. The components of good character

Moral knowing enclosing moral awareness, knowing the moral value, perspective taking, moral reasoning, decision making, self-knowledge is the knowledge that is taught to face moral challenges that occur in life. Moral feeling enclosing conscience, selfesteem, empathy, leaving the good, self-control and humanity is a value that needs to be cultivated in order to become a man who is honest, fair, respectful towards each other. Moral action enclosing competence, will, and a habit is an act of real moral knowledge of moral feeling and to be able to realize the good character in people.
The development of values education in Indonesia identified character derived from four sources. The first is a religion, people of Indonesia is a community and a nation that is always based on the teachings of religion and belief. The second is Pancasila, there is a preamble in 1945 that divided into chapters with the values regulate in political life, law and economy, community, culture and the arts. The third is the culture, the culture that is relied upon in the awarding of the meaning of a concept and the meaning of communication with fellow human beings. The fourth is the National Education goals listed in the law of Republic Indonesia Number 20 the year 2003 about national education system formulates the function and purpose of national education [19].

Ministry of National Education Agency research and development center of the curriculum [20] develop character values the adoption of the philosophy of education character Ki Hajar Dewantara which include though hearts (ethics), sports (kinesthetics), though think (literacy), and though aesthetics. 18 of these values include religious, honest, tolerance, discipline, hard work, creative, independent, democratic, curiosity, national spirit, love of the homeland, respect for achievement, communicative, love of peace, love of reading, care for the environment, social care, and responsibility. Then, 18 of the values character crystallized into five core values include religious, nationalist, independent, mutual and integrity that is adapted to the National Revolution Movement of Metal, wisdom creativity and local schools with strengthening character education program name that is contained in the regulation number 87 Years 2017 about strengthening character education. Five major interrelated and form a network a priority in strengthening character education.

TABLE.I. THE FIVE MAIN CHARACTERS IN THE VALUE OF STRENGTHENING CHARACTER EDUCATION

\begin{tabular}{|c|c|c|c|}
\hline No & Value & Description & Sub Values \\
\hline 1 & Religious & $\begin{array}{l}\text { Reflecting the } \\
\text { attitude of faith in } \\
\text { God Almighty } \\
\text { who is manifested } \\
\text { in behavior } \\
\text { carrying out } \\
\text { religious teachings } \\
\text { and beliefs are } \\
\text { adhered to, } \\
\text { appreciate the } \\
\text { difference } \\
\text { religion, of } \\
\text { upholding the } \\
\text { tolerant attitude of } \\
\text { religious worship } \\
\text { and } \\
\text { implementation } \\
\text { other beliefs, } \\
\text { pillars and living } \\
\text { peacefully with } \\
\text { other adherents. }\end{array}$ & $\begin{array}{l}\text { Tolerance, love of } \\
\text { peace, friendship, } \\
\text { firm establishment, } \\
\text { sincerity, } \\
\text { confidence, and } \\
\text { violence, does not } \\
\text { impose the will, } \\
\text { loving environment, } \\
\text { cooperation between } \\
\text { different religions } \\
\text { and beliefs, } \\
\text { appreciate the } \\
\text { difference of religion } \\
\text { and belief, protect } \\
\text { small and } \\
\text { marginalized. }\end{array}$ \\
\hline
\end{tabular}




\begin{tabular}{|c|c|c|c|}
\hline 2 & $\begin{array}{l}\text { The } \\
\text { Nationali } \\
\text { st }\end{array}$ & $\begin{array}{l}\text { Ways of thinking, } \\
\text { being and doing } \\
\text { that show of } \\
\text { loyalty, care, and } \\
\text { appreciation } \\
\text { towards language, } \\
\text { the physical } \\
\text { environment, } \\
\text { social, culture, } \\
\text { economy and } \\
\text { politics of the } \\
\text { nation, put the } \\
\text { interests of the } \\
\text { nation and the } \\
\text { country above } \\
\text { self-interest and } \\
\text { his group. }\end{array}$ & $\begin{array}{l}\text { Appreciation of the } \\
\text { culture of the nation } \\
\text { itself, keeping the } \\
\text { nation's cultural } \\
\text { beliefs, willing to } \\
\text { sacrifice, superior } \\
\text { and overachievers, } \\
\text { love the motherland, } \\
\text { safeguard the } \\
\text { environment, law- } \\
\text { abiding, discipline, } \\
\text { respect for cultural } \\
\text { diversity, tribe and } \\
\text { religion. }\end{array}$ \\
\hline 3 & $\begin{array}{l}\text { Standalo } \\
\text { ne }\end{array}$ & $\begin{array}{l}\text { The attitude, } \\
\text { which is not } \\
\text { dependent on } \\
\text { others and using } \\
\text { energy, mind, time } \\
\text { to realize the } \\
\text { hopes, dreams, } \\
\text { and goals. }\end{array}$ & $\begin{array}{l}\text { Work ethic (hard } \\
\text { work), a tough, } \\
\text { sturdy, has a fighting } \\
\text { power, } \\
\text { professional, } \\
\text { creative, have the } \\
\text { courage, to become } \\
\text { lifelong learners. }\end{array}$ \\
\hline 4 & Mutual & $\begin{array}{l}\text { The attitude or } \\
\text { action which } \\
\text { reflects the } \\
\text { existence of a } \\
\text { spirit rits } \\
\text { cooperation and } \\
\text { digging resolve } \\
\text { the issue together. }\end{array}$ & $\begin{array}{l}\text { Appreciate each } \\
\text { other, inclusive, } \\
\text { cooperation, } \\
\text { solidarity, have a } \\
\text { sense of empathy, a } \\
\text { commitment to joint } \\
\text { decisions, } \\
\text { deliberations, } \\
\text { consensus please } \\
\text { help, anti- } \\
\text { discrimination, } \\
\text { nonviolence and has } \\
\text { an attitude toward } \\
\text { volunteerism. }\end{array}$ \\
\hline 5 & $\begin{array}{l}\text { The } \\
\text { integrity } \\
\text { of the }\end{array}$ & $\begin{array}{l}\text { Is an attempt to } \\
\text { establish himself } \\
\text { as the man who } \\
\text { could always be } \\
\text { trusted with } \\
\text { words, actions and } \\
\text { so on. }\end{array}$ & $\begin{array}{l}\text { Honesty, justice, } \\
\text { fidelity example, } \\
\text { appreciate the } \\
\text { dignity of the } \\
\text { individual } \\
\text { (especially persons } \\
\text { with disability), anti- } \\
\text { corruption, moral } \\
\begin{array}{l}\text { commitment, } \\
\text { responsibility and } \\
\text { love of truth. }\end{array}\end{array}$ \\
\hline
\end{tabular}

Source: Concept and guidelines for strengthening character education, Kemdikbud RI [20]

Implementation strengthening educational programs including character is divided into a base class, the base classes and base culture society conducted through multiple strategies and approaches. The strategies in character education that can be done through attitude example, planting of discipline and conditioning. The strategy was carried out in an environment of family, school and community environment [21]. There are several approaches to character education, include: (a) character education in formal and non-formal education units must be conditioned as main support activities as well as showing the example that reflects the values of the characters want to be developed; (b) the character of the learning is done through a variety of activities in the classroom, informal and non-formal education units, and outside unit of education; (c) the development of the character can be seen in the background at the macro and micro background; (d) strengthening the response from character education to be done in the long term and repeated constantly; (e) the assessment of character education can be done against the performance of educators, educational personnel, educators, and learners [22].

\section{The Context of Citizenship Education}

Development citizenship education started in America from the teaching of civic that adopted many of the practices of democracy by civilians in the citystate in ancient Greece who then take political science portion in the form of political democracy is then added material community civics, civics and vocational economic civics to teach in schools and continues on community civic movement and movement civic education with characteristics that are able to accommodate a variety of needs that are required in developing learners or a citizen in a democracy society known for its Civic-Plus [23].

The subject's civic education in Indonesia is also experiencing growth in the term used, recorded in history after the proclamation of independence. In 1957 the term used is a Nationality with the contents of the discussion about how to gain and lose their citizenship status [23]. Started in 1959 turned into a Civic is characterized by the occurrence of a change of political direction the country Indonesia, by Presidential Decree of 5 July 1959 Constitution 1945 applies again. At the time of the civic were introduced as a lesson in High School and Junior High School level, the national history, the history-charged proclamation, UUD 1945, Pancasila, the State of the union speeches President and fostering national unity. The source used books New Indonesia Human and Civic Seven Staples Indoctrination, known as CSSI.

In 1962 the Civic changed to Commonwealth Countries, followed by a change of the content of the material by removing the President's Speech because his ideas were judged less in accordance with the efforts to implement the 1945 Constitution and the Pancasila. In 1968 the term was known as Citizenship Education, then with the introduction of the curriculum using the term Science 1972 State Citizenship through the national seminar on the teaching of Civic education. Then through the 1975 curriculum, the term appears with the name of Pancasila Moral Education subjects. Through the decision of the Minister no. 0209/U/1984, regarding the Curriculum Improvement High School levels above, engender governance subjects never was introduced along with the subjects Civics and Tata Law in 1957. Until the year 1989, the term used is education citizenship [23]. 
The Government continues to provide the form of his attention on the development of civic education subjects. Through the curriculum was changed the term 1994 civics and Citizenship (PPKn). During this period the charge material PPKn have started growing on a wider level following a State order changes with the addition of the scope of the material. In the paradigmatic, citizenship education has the vision of socio - pedagogical educate democratic citizens in a broader context, which includes the context of formal education and nonformal education [24].

Based on the 1994 curriculum, the subjects have a function PPKn which include: (a) preserve and develop moral values of Pancasila in order to answer the challenge of the development occurring in the Community; (b) develop and nurture learners become fully conscious human Indonesia politics, the law and the Constitution based on Pancasila; (c) fostering awareness and understanding of the relationships between State and State Defense education to carry out its rights and responsibilities as citizens; and (d) equip participants with attitude and behavior reflecting the values of Pancasila [23].

The reform era in the year 2000 give effect on charge PPKn with the ability skill that gave birth to the competency-based Curriculum (KBK), these changes come into bringing about change term of PPKn be citizenship education. The curriculum determines the PKn in the level of elementary and Junior High School was integrated about education social studies, at the high school level was made stand-alone subjects [25].

As the PKN subjects which have an important role in forming good citizens in accordance with the philosophy of the nation and the Constitution of the Republic of Indonesia. Generally subjects PKn consists of (a) the civics knowledge covering the areas of politics, law, and morals; (b) the dimensions of the civics skills includes the skills of participation in the life of nation and State; and (c) the values of the dimensions of citizenship (civics disposition) include, among others, confidence, commitment, self-mastery over religious values [26].

KBK is replaced by a curriculum unit-level education (KTSP) there is the Year 2006. Through Permendiknas No. 22 the year 2006 about Standard Contents states that subjects of PKn in Junior High School and elementary level are no longer integrated into Social Science subjects but stands on its own [25]. Lasted long enough to KTSP in 2013, steering replaced by 2013 Curriculum (K-13). Turn the curriculum brings the change back on subjects PKn into civics and Citizenship.

\section{METHODOLOGY}

Writing this using the method of librarianship, namely writing using a variety of source readings from books, journals, news, online media and other reading resources that can be used as a source in the writing. Data collection techniques in the writing are done by collecting a variety of source readings that can support and in accordance with the purpose of writing. Sourced from various readings later in the analysis so that it can be summed up as the results of research in the writing of this.

\section{RESULTS AND DISCUSSION}

Citizenship Education is defined in a number of concepts approaches, namely: (a) education of citizenship focus on giving of meaning and knowledge learners against national history and values related to social life the Government; (b) citizenship education involves the active role of learners to participate in the school community, or outside the school in developing a knowledge component, and (c) education for citizenship, including two involving knowledge and skills of learners through the character values that enable them to participate actively and wisely by taking the role of responsibility in the face of life [24].

The need for civic education in the emphasis on active participation in civil rights and democratic rights [27]. The PKn is full participation of reason and responsibility in the political life of the citizen which adhere to the values and principles of constitutional democracy Indonesia. Effective citizen participation and full responsibility require mastery of a set of scientific and intellectual skill as well as the skills to participate. Effective participation and responsibility also were enhanced further through more development disposition or specific figures to increase the ability of individuals participate in the political process and support the functions of a healthy political system and the improvement of society [28].

$\mathrm{PKn}$ in Indonesia has three principal functions, i.e., develop the civic intelligence, foster the civic responsibility, and encourage the civic participation that diwujudkan with the mission run PKn, include: (a) as political education with political literacy, political awareness, as well as the ability to political participation; (b) as value education, through embedded and transformed PKn expected values, morals, and norms that are considered by both the nation and the country to learners, so support for the efforts of the nation and character building. In this case, the values-values of Pancasila should still be the main reference in the educational efforts of this value; (c) education as nationalism, is expected to be grown and improved sense of nationalism or national learners, so they are more loving, feel proud, and willing to sacrifice for the nation and the country; (d) as a legal education, that education is directed to foster the students as citizens who have high legal awareness, which is aware of its obligations and rights, and have a high legal compliance; (f) as multicultural education, are expected to increase insight and tolerant attitude of the learners for life in a society that is multicultural; (6) as the conflict resolution education, nurture learners to be able to resolve conflicts constructively [29]. 
The unequivocal mission of the PKn, namely: (a) education as the PKn democracy task prepare learners to become citizens of a democratic State to support democratic upright State; (b) the duty of fostering and developing the PKn knowledge and ability learners with regard to the role, duties, rights, obligations and responsibilities as citizens in a variety of aspects of the life of a country as the nation's democratic values the threat through intra or extra lessons in school; (c) education as the PKn defend the country in charge of forming the learners to have consciousness and feelings of love towards the country, nation and culture, so that reliable for maintaining the sustainability of the State; and (d) as the PKn values education and character in charge of fostering and building democracy citizen culture programmatically, hard-wired, and well organized [30].

The Mission of the PKn, namely: (a) a psychopedagogical mission develop potential learners progressively and sustainable (b) psychosocial mission which aims to facilitate learners as sentient social by becoming a citizen of Indonesia, democratic, lawabiding, civilized, and religious; (c) sociocultural which facilitates the realization of ideas, unbelief system/values, concepts, principles, and the praxis of democracy in the context of the development of civil society creatively Indonesia which boils down to growing and important moral commitment and social citizenship, generalizations about civic virtue or virtues of citizenship and civic culture or cultural citizenship [31].

Research activity conducted [24] claimed that PKn interpreted in a maximum and minimum version by looking at two factors. Starting with the contextual factor, include the historical traditions, geographical position, socio-political structures, economic systems and trends of global. Then look at the detail of structural factors, including the Organization and responsibility for education, regulation, holding of values education and educational purposes.

See mission, function, and purpose of the PKn is already so widespread has values, then the PKn in Indonesia on its implementation already follows the interpretation of the maximum. In the Maximum interpretation [29], PKn developed the ability, independence and reflective critical thoughts about social issues, and the ability to participate actively in the social and political processes. Interpretation up to more power and more functional to develop democracy in Indonesia. By using maximal interpretation approach and through the tradition of reflective inquiry, PKn now more expected to solve problems of implementation the values of Pancasila and nationalism in a more critical and democratic. While minimal Interpretation means simply demanding a discussion into the knowledge base of rules that has been work related to the rights and obligations of citizens.
As the PKn Efforts education values of Pancasila and the strengthening of national character is already done since the reign of President Sukarno years 1960, within the framework of nation and character building. An attempt is made to realize customized Indonesia citizens with political vision and mission of the rulers at that time. Therefore, the materials that any given not just about Pancasila and the 1945 Constitution, but also materials that contain political views [29]. Internalization of the values contained in the PKn is the values taught in schools with teaching materials of PKn charge that covers on the knowledge, skills, and attitudes [32]. The details can be seen in table 2 .

TABLE II. THE CHARGE MATERIAL TEACHING SUBJECTS PKN

\begin{tabular}{|c|c|c|}
\hline $\begin{array}{c}\text { Aspects of } \\
\text { the } \\
\text { Knowledge }\end{array}$ & $\begin{array}{l}\text { Aspects of the } \\
\text { Skills }\end{array}$ & $\begin{array}{l}\text { Aspects of the } \\
\text { The attitude of the }\end{array}$ \\
\hline $\begin{array}{l}\text { - } \text { governance } \\
\text { structure } \\
\text { - legislation } \\
\text { - rights and } \\
\text { obligations } \\
\text { - taxation } \\
\text { - State } \\
\text { Government } \\
\text { - political } \\
\text { system } \\
\text { - human right } \\
\text { - multicultural } \\
\text { ism } \\
\text { - on violence }\end{array}$ & $\begin{array}{l}\text { - listen to opinion } \\
\text { other people } \\
\text { - transmit the } \\
\text { opinion of the } \\
\text { - critiquing public } \\
\text { policy } \\
\text { - communicate } \\
\text { - responsible } \\
\text { - comply with } \\
\text { regulations } \\
\text { - familiarize } \\
\text { queued } \\
\text { - read the } \\
\text { information } \\
\text { - write } \\
\text { - think } \\
\text { - led Councils/ } \\
\text { meetings } \\
\text { - write a letter/ } \\
\text { petition/decision. }\end{array}$ & $\begin{array}{l}\text { - } \text { awareness of } \\
\text { nationality/ } \\
\text { nationalism } \\
\text { - } \text { respect the } \\
\text { symbols of the } \\
\text { Union } \\
\text { - } \text { honesty } \\
\text { - strict laws } \\
\text { - discipline } \\
\text { - tolerance } \\
\text { - respect the dignity } \\
\text { and human dignity } \\
\text { - appreciate the } \\
\text { opinions of others } \\
\text { - nonviolence } \\
\text { - multiculturalism } \\
\text { - do not } \\
\text { discriminate based } \\
\text { on the human } \\
\text { tribe, religion, } \\
\text { race, color etc. }\end{array}$ \\
\hline
\end{tabular}

Strengthening the Foundation of character education implementation axis-based classes, the school, and the community. In the classroom, the strengthening of character education is integrated into the subjects. Citizenship education has the goal of making good citizens based on the values of Pancasila in charge of values education for citizens. The key to value education lies in cultivating noble values [33], among which include: (a) love of God; (b) responsibility, discipline and independence; (c) honesty/mandate and wise; (d) respect and manners; (e) the generous, helpful and royong; (f) confident, creative and hard-working; (g) leadership and fairness; (h) good and humble, tolerance, peace and unity. As the PKn approach values education can be done in several ways such as Evokasi that emphasizes on the initiative of learners to express himself in spontaneous, Inculcation (embed), approach to awareness, moral reasoning, analysis of the value, the value of disclosure, commitment and approach combines, approach modeling exemplary damages, and education based on the character [34]. 


\section{CONCLUSION}

Citizenship education is a strategic subject as educational value and strengthening character education with strategies and approaches to develop awareness of the learner in order to realize himself as heir to the nation must internalize the sublime values of Pancasila that has been excavated and formulated by the founder of the Republic of Indonesia. Then to provide the cornerstone of broad knowledge and insight and confidence values of Pancasila to learners as the provision of community life, as an individual and a civilized social being in the Association community, the nation, and the world. Further, develop the potential values of Pancasila moral maturity to achieve in diversity and equality of human beings as individuals and social life of society.

The development of values in character education in Indonesia comes from religion, Pancasila, cultural and educational purposes a national one based implementation class with integrated on subjects. The values contained in the Pancasila is the charge on civic education. Citizenship education has emerged with different terms and programs, but essentially these subjects aim at forming good citizens. The PKn as values education and strengthening of character education in the hopes of forming citizens who have knowledge, skills and values/dispositions. The third thing that but can be synergized and will deliver competent citizens, committed and confidence as citizens, and expected to take a decision in the matter of solving problems related to the life of the citizen.

The values of Pancasila in PKn and the strengthening of national character education taught in school be cultivated and includes the granting of knowledge and insight into the basics of aesthetic value, ethics, moral law and culture as the Foundation to honor and appreciate between fellow human beings so that the community will be realized that regular and orderly, prosperous, then granting foundations for understanding social and cultural issues as well as being able to be critical, analytical and responsive to solve problems in wise in the community.

\section{REFERENCES}

[1] Latif, Y., “Negara paripurna,” Jakarta: PT Gramedia Pustaka Utama, 2011.

[2] Ratna, Ny. K., Peranan karya sastra, seni, dan budaya dalam pendidikan karakter," Yogyakarta: Pustaka Pelajar, 2014.

[3] Kalidjernih, F.K., "Puspa ragam konsep dan isu kewarganegaraan," Bandung: Widya Aksara Press, 2011.

[4] Patinus, R., Parwadi, \& Donatianus, "Kenakalan Remaja di Kalangan Siswa-Siswi SMPN 07 Sengah Temila Kecamatan Sengah Temila Kabupaten Landak," Jurnal Program Magister Ilmu Sosial Universitas Tanjungpura, 2013.

[5] Aryanto, H., Wibowo \& Santosa, H.S., "Perancangan permainan interaktif mengenai cinta tanah air untuk kalangan usia 11-17 Tahun," Jurnal DKV Adhiwana 1 (2), 2013, pp. $1-15$
[6] Cogan, J. J. \& Derricot, R., “Citizenship for the 21st Century: An International Perspective on Education, ” London: Cogan Page, 1998.

[7] Latif Y., “Revolusi Pancasila,” Bandung: Mizan Media Utama, 2015.

[8] Kaswardi, E. M. K., "Pendidikan nilai memasuki tahun 2000, ” Jakarta: Gramedia Widiasaran Indonesia, 1993.

[9] Koesoema, A. D., "Pendidikan karakter utuh dan menyentuh," Yogyakarta: Penerbit Kanisius, 2012.

[10] Bertens, K., “Etika, ” Yogyakarta: PT. Kanisius, 2013.

[11] Elmubarok, Z., “Membumikan pendidikan nilai,” Bandung: Alfabeta, 2009.

[12] Mulyana, R., “Mengartikulasi pendidikan nilai,” Bandung Alfabeta, 2011.

[13] Notonagoro, "Pancasila secara ilmiah popular," Jakarta Pantjuran Tujuh, 1975.

[14] Kemendikbud, "Pemaparan Gerakan Penguatan Pendidikan Karakter," http://cerdasberkarakter.kemdikbud.go.id/content/modul_dan buku_saku?page=5, Retrieved 22 Oktober, 2017.

[15] Hoge, J., "Character education, citizenship education and the social studies," Social Studies 93 (3), 2002, pp.103-109.

[16] Mulyasa, E., “Manajemen pendidikan karakter,” Jakarta: Bumi Aksara, 2013.

[17] Gufron, A., "Integrasi nilai karakter bangsa pada kegiatan belajar," Jurnal Cakrawala Pendidikan. Eds Khusus dies natalis: $13-24$

[18] Lickona, T., "Pendidikan karakter: panduan lengkap mendidik siswa menjadi pintar dan baik," Bandung: Nusa Media, 2013

[19] Hasan, S. H., et al., "Pengembangan pendidikan budaya dan karakter bangsa," Jakarta: Kementerian Pendidikan Nasional Badan Penelitian dan Pengembangan Pusat Kurikulum, 2010.

[20] Badan Standar Nasional Pendidikan, "Laporan BSNP Tahun 2010," (http://www.bsnp-indonesia.org/id/wpcontent/uploads/2012/04/Laporan-BSNP-2010.pdf ), Retrieved 13 Oktober, 2017.

[21] Hidayatullah, F., “Membangun peradaban bangsa," Surakarta: Yuma Pustaka, 2010.

[22] Murdiono, M., "Pemanfaatan Lingkungan Sosial sebagai Media Pembelajaran Pendidikan Kewarganegaraan," Majalah Ilmiah Pembelajaran, 4 (1), 2008, pp. 92-105

[23] Cholisin, et. al., "Ilmu kewarganegaraan," Jakarta: Universitas Terbuka, 2007.

[24] Keer, D., "Citizenship education: An international comparison," London: Quality Curriculum Association, 1999.

[25] Murdiono, M., "Pemanfaatan Lingkungan Sosial sebagai Media Pembelajaran Pendidikan Kewarganegaraan," Majalah Ilmiah Pembelajaran, 4 (1), 2008, pp. 92-105.

[26] Branson, M.S., "Belajar civic education dari Amerika," Yogyakarta: LKIS, 1999.

[27] Print, M., "Civics and Values in the Asia Pacific region," Asia Pacific Journal of education, 20, 2000, pp. 7-20.

[28] Rahmat, et. al., "Pembelajaran Pendidikan Kewarganegaraan," Bandung: Laboratorium Pendidikan Kewarganegaraan FPIPS UPI, 2009.

[29] Maftuh, B., "Internalisasi nilai-nilai Pancasila dan nasionalisme melalui Pendidikan Kewarganegaraan," Jurnal Educationist, 2 (2), 2008, pp. 134-144.

[30] Winarno, "Paradigma Baru Pendidikan Kewarganegaraan Panduan Kuliah di Perguruan Tinggi," Jakarta: PT Bumi Aksara, 2013.

[31] Winataputra, U. S., "Posisi akademik pendidikan kewarganegaraan (PKn) dan muatan/mata pelajaran Pendidikan Pancasila dan Kewarganegaraan (PPKn) dalam konteks sistem pendidikan nasional," Jurnal Moral Kemasyarakatan, 1 (1), 2016, pp. 15-36. 
[32] Azwar, A., "Pendidikan Kewarganegaraan dan pendidikan karakter bangsa," Jurnal Demokrasi I1 (1), 2012, pp. 258283.

[33] Saputra, E., "Eksistensi PKn sebagai pendidikan nilai dalam membangun karakter bangsa," TINGKAP, 8 (2), 2012, pp. $145-158$

[34] Agus, A. A., "Pendekatan pendidikan kewarganegaraan sebagai pendidikan nilai moral di sekolah dasar," Jurnal Supremasi, 10 (1), 2015, pp. 36-41. 